\title{
COMPLEXES OF ZINC WITH PICOLINIC AND ASPARTIC ACIDS INACTIVATE FREE VARICELLA-ZOSTER VIRIONS
}

\author{
S. Shishkov1, T. Varadinova*1, P. Bontchev2 , C. Nachev ${ }^{3}$ and E. Michailova1 \\ 1 Laboratory of Virology, Faculty of Biology, University of Sofia, 8 Dragan Tzankov Blvd., 1421 Sofia, Bulgaria \\ 2 Faculty of Chemistry, Univesity of Sofia, Bulgaria \\ 3 Higher Medical Institute, Sofia. Bulgaria
}

Abstract

$\mathrm{Zn}$ (II) picolinate and aspartate, $\mathrm{Zn}(\mathrm{pic})_{2}$ and $\mathrm{Zn}(\mathrm{asp})_{2}$, have been shown to inhibit key steps of the replication of HSV-1. In the present study we describe the effect of $\mathrm{Zn}(\text { pic })_{2}$ and $\mathrm{Zn}(\mathrm{asp})_{2}$ on the replication of VZV and on the infectivity of free virions. The experiments are done using BHK-21 cells, a clinical isolate of VZV and Zn-complexes in concentration of $10 \mu \mathrm{M}$. When Zn-complexes are present during the whole period of infection, the yield of infectious virus progeny decreases up to $98 \%$. The infectivity of VZV is completely restored after the removal of zinc. The virucidal effect is manifested at the 2 nd $h$ of contact, when $90 \%$ of the virions are inactivated. The results show that both $\mathrm{Zn}(\text { pic })_{2}$ and $\mathrm{Zn}(\mathrm{asp})_{2}$ specifically inactivate free VZV virions with no effect on viral replication. Key words: Varicella-zoster virus, zinc, replication, inhibition, inactivation.

\section{Introduction}

Varicella-zoster virus (VZV) belongs to the genus Varicellovirus of the subfamily Alphaherpesvirinae, family Herpesviridae (1). Members of the same subfamily are also Herpes simplex viruses types 1 and 2 (2). Despite structural and antigenic relationships, significant differences in biological properties between VZV and Herpes simplex virus (HSV) are evident. Thus, VZV is mainly cell associated $(1,3,4)$. The virus uses a noncanonical transcription start and stop sites. The fully assembled nucleocapsids mature by two step envelopment - during the transport through inner nuclear membrane and during the migration into vacuoles. Within these vacoules, mature virions migrate to the cell periphery and are released by exocytosis $(1,5)$.

Because of the unique biological properties, the problems of therapy and control of VZV infection are still open. The current treatment of VZV infection for humans is based on Acyclovir (6). Despite the modestly shortened duration of varicella and zoster symptoms and the prevention of the spread of zoster to the eye in normal individuals, the existence of Acyclovir resistant VZV strains have been reported $(1,3,7,8)$. Other agents used in therapy of VZV infection are Vidarabine and alpha-Interferon $(9,10)$.

Our previously published data have shown that $\mathrm{Zn}(\mathrm{pic})_{2}$ and $\mathrm{Zn}(\mathrm{asp})_{2}$ inhibit key steps of HSVreplication $(11,12)$. However, the effect of these $\mathrm{Zn}$-complexes on VZV infection in vitro is also of interest.

\section{Materials and Methods}

Varicella-zoster virus and cells. A clinical isolate of VZV adapted for replication in vitro and BHK-21 cell line were used. The viral stock was obtained from BHK-21 cells cultured for $72 \mathrm{~h}$ at $37^{\circ} \mathrm{C}$ and then frozen and thawed.

Infectious virus titre. Tube cells from suspension in amount of $0.9 \mathrm{ml}$ were infected with $0.1 \mathrm{ml}$ of VZV stock in ten-fold dilutions. After culturing at $37^{\circ} \mathrm{C}$ for $72 \mathrm{~h}$ the infectious virus titre was determined by Reed and Muench (13).

Effect of $Z n$-complexes on the replication of $V Z V$. Simultaneously, $0.1 \mathrm{ml}$ of media modified with 10 $\mu \mathrm{M}$ or $1 \mu \mathrm{M}$ of each $\mathrm{Zn}$-complex and $0.1 \mathrm{ml}$ of VZV stock in various dilutions were added to $0.8 \mathrm{ml}$ of cells from suspension. One set of infected cells served as untreated control.

The effect on VZV replication was determined by reduction of infectious virus titres as compared to that from untreated control at the $72 \mathrm{nd} \mathrm{h}$ after culturing at $37^{\circ} \mathrm{C}$.

Reversibility of the inhibitory effect. Samples from the above experiments containing $1000 \mathrm{pfu} / 0.1$ $\mathrm{ml}$ of VZV and an appropriate concentration of each $\mathrm{Zn}$-complex, as well as that from untreated controls, were frozen, thawed and diluted ten-fold. BHK-21 cells suspended in nonmodified 
medium were infected with appropriate dilution from each sample. The reversibility of the effect of $\mathrm{Zn}$-complexes on the replication of VZV was determined by the restoration of viral infectivity as compared to that of the untreated control.

Effect of Zn-complexes on extracellular (free) VZV virions (virucidal effect). Equal volumes of VZV stock containing $100 \mathrm{pfu} / \mathrm{ml}$ and media modified with $10 \mu \mathrm{M}$ of appropriate $\mathrm{Zn}$-complex were incubated at $37^{\circ} \mathrm{C}$ for $15 \mathrm{~min}, 30 \mathrm{~min}, 1 \mathrm{~h}, 2 \mathrm{~h}, 4 \mathrm{~h}$ and $12 \mathrm{~h}$. Each sample was diluted ten-fold and $0.9 \mathrm{ml}$ suspended cells were infected with $0.1 \mathrm{ml}$ of each dilution. The virucidal effect was determined at the $72 \mathrm{nd} h$ by reduction of infectious virus titres as compared to that of the viral control - equal volumes of VZV stock and unmodified medium incubated as described above.

\section{Results}

The data presented in Table 1 show that $\mathrm{Zn}(\text { pic })_{2}$, as well as $\mathrm{Zn}(\mathrm{asp})_{2}$, in a concentration of $10 \mu \mathrm{M}$, but not of $1 \mu \mathrm{M}$, inhibit the replication of VZV in BHK-21 cells by $98 \%$ and $90 \%$ respectively, as compared to the untreated viral control.

The inhibitory effect is reversible (Table 1). Thus, after treatment with $\mathrm{Zn}(\text { pic })_{2}$, the infectivity of VZV is completely restored while, after influence with $\mathrm{Zn}(\mathrm{asp})_{2}, 73 \%$ of the viral progeny reversed their infectious activity.

Table 1

Effect of $\mathrm{Zn}(\mathrm{pic})_{2}$ and $\mathrm{Zn}(\mathrm{asp})_{2}$ on the replication of $\mathrm{VZV}$ and the reversibility of the action

\begin{tabular}{lccccc}
\hline Zn-complex & $\begin{array}{c}\text { Consentration } \\
\text { in } \mu \mathrm{M}\end{array}$ & $\begin{array}{l}\text { Reversibility } \\
\text { replication }\end{array}$ & \multicolumn{2}{l}{ of the action } & \\
\hline $\mathrm{Zn}\left(\right.$ pic) ${ }_{2}$ & 10 & $6.2^{\mathrm{a}}$ & $98^{\mathrm{b}}$ & $3.6^{\mathrm{a}}$ & $0^{\mathrm{b}}$ \\
& 1 & 7.8 & 0 & n.d. & \\
$\mathrm{Zn}(\text { asp })_{2}$ & 10 & 6.9 & 90 & 3.5 & 27 \\
$\mathrm{VZV}$ control & 1 & 7.9 & 0 & n.d. & \\
\hline
\end{tabular}

${ }^{a}$ lg pfu/0.1 ml; ${ }^{b}$ Inhibition in \%; n.d. - not done

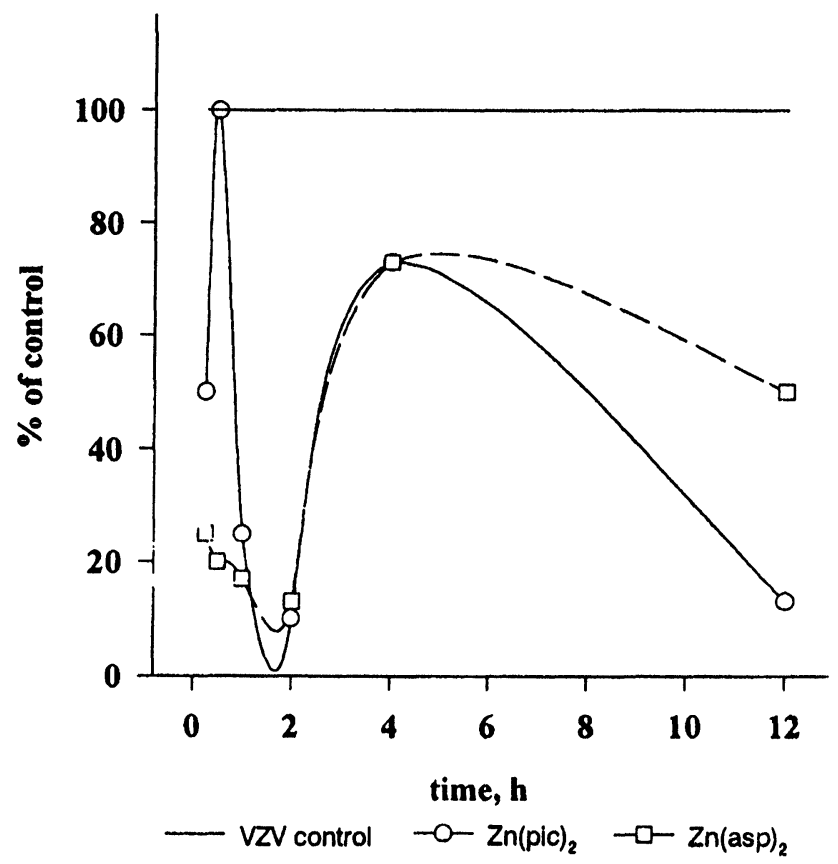

Fig. 1: Virucidal effect of $\mathrm{Zn}(\mathrm{pic})_{2}$ and $\mathrm{Zn}(\text { asp })_{2}$ 
In order to clarify why the replication of VZV was inhibited in the presence of $\mathrm{Zn}$-complexes and is completely restored immediately after removing zinc, we studied the effect of these complexes on extracellular virions.

Table 2

Effect of $\mathrm{Zn}(\text { pic })_{2}$ and $\mathrm{Zn}(\mathrm{asp})_{2}$ on extracellular VZV virion - virucidal effect ${ }^{*}$

\begin{tabular}{lcccccc}
\hline Zn-complex** & \multicolumn{7}{c}{ Duration of the contact } \\
\cline { 2 - 7 } & $15 \mathrm{~min}$ & $30 \mathrm{~min}$ & $1 \mathrm{~h}$ & $2 \mathrm{~h}$ & $4 \mathrm{~h}$ & $12 \mathrm{~h}$ \\
\hline $\mathrm{Zn}(\text { pic) })_{2}$ & 7.6 & 6.9 & 5.7 & 5.0 & 5.3 & 4.1 \\
Zn(asp) $_{2}$ & 7.3 & 6.2 & 5.5 & 5.1 & 5.3 & 4.7 \\
VZV control & 7.9 & 6.9 & 6.3 & 6.0 & 5.5 & 5.0 \\
\hline
\end{tabular}

"data are presented as lg pfu/0.1 ml

"each complex is applied in a concentration of $10 \mu \mathrm{M}$ measured by $\mathrm{Zn}(\mathrm{II})$

The results presented in table 2 and fig. 1 show two sets of data. First - the specific dynamics of the virucydal effect of $\mathrm{Zn}$-complexes manifested between the $2 \mathrm{nd} \mathrm{h}$ and 12th $\mathrm{h}$ of the contact with free VZV. Thus, at the 2nd and 12th $\mathrm{h}$ after contact, $90 \%$ and $87 \%$ respectively of VZV virions are inactivated. In contrast, at the 4th h only $17 \%$ of the free VZV are inactivated. Second - the virucidal effect of $\mathrm{Zn}$-complexes during the first two hours of contact with VZV virions depends on the ligands of $\mathrm{Zn}$ (II). Thus, $\mathrm{Zn}(\mathrm{asp})_{2}$ affects free VZV soon after the contact and at the 15 th $\mathrm{min} 75 \%$ of the virions are already inactivated. The effect increases with the prolongation of the contact up to the 2 nd $h$. ${ }^{3}$ Conversely, $\mathrm{Zn}(\mathrm{pic})_{2}$ inactivates free VZV $1 \mathrm{~h}$ after the contact with prolongation of the effect till the 2 nd $h$.

\section{Discussion}

The data presented here show that when suspended BHK-21 cells are influenced with VZV and $\mathrm{Zn}(\text { pic })_{2}$ or $\mathrm{Zn}(\mathrm{asp})_{2}$, viral replication is inhibited by $90-98 \%$. According to the experimental protocol, two events proceed simultaneously on the plasma membrane - viral attachment and absorption of $\mathrm{Zn}$-complex. During their movement from the medium to the cell surface $\mathrm{Zn}$-complex and VZV particles can interact with each other. It is well known that the VZV envelope originates from cell membranes modified by viral glicoproteins $(4,5)$. That is why we suggest that the inhibition of VZV replication by $\mathrm{Zn}$-complex is due to the specific kinetics of $\mathrm{Zn}$ (II) exposure onto membranes (12) rather than to the direct effect on viral replication into host cells. The following three sets of results are in accordance with this suggestion. Firstly, the complete restoration of VZV infectivity after removal of zinc (table 1). Secondly, a weak effect of $10 \mu \mathrm{M} \mathrm{Zn(pic)})_{2}$ on the replication of $\mathrm{tk}^{+}$and $\mathrm{tk}^{-}$strains of VZV, obtained by Dr. J. Neits (data not published) from the team of Prof. E. De Clercq (Rega Institute for Medical Research, Katholieke Universiteit, Leuven). In these experiments $\mathrm{Zn}(\mathrm{pic})_{2}$ has been added after VZV attachment. Thirdly, inactivation of free VZV virions on the $2 n d h$ after contact with $\mathrm{Zn}(\mathrm{pic})_{2}$ or $\mathrm{Zn}(\operatorname{asp})_{2}$ (table 2, fig. 1).

In addition, the ligand of $\mathrm{Zn}$ (II) determines the duration and the degree of the inactivating effect of this ion on VZV virions. Thus, aspartic acid ensures quick and a prolonged (at least $2 \mathrm{~h}$ ) virucidal effect of $\mathrm{Zn}$ (II). On the other hand, picolinic acid predetermines a brief and delayed effect on free virions which is manifestated between 1 st and 2 nd $h$.

The different effects of $\mathrm{Zn}(\mathrm{pic})_{2}$ and $\mathrm{Zn}(\mathrm{asp})_{2}$ on VZV and HSV replications are obviously due to the specific biological properties unique to both viruses.

Acknowledgements: This work is financially supported by grants $X-15$ and $L-451$ from the National Foundation for Science. 


\section{References}

1. J.I.Cohen, S.E. Straus, W.T. Ruyechan, J.Hay. In: Encyclopedia of Virology. R.E. Webster, A. Granoff (eds.), Acad. Press, New York, 1994, v.3, 1514.

2. L. Aurelian. In: Encyclopedia of Virology. R.E. Webster, A. Granoff (eds.), Acad. Press, New York, 1994, v.2, 587.

3. S.E. Straus, I.M. Ostrove, G. Inchauspe, J.M. Felsez, A. Freifild, K.D. Kroen, M.H. Sawyer. Ann. Intern. Med. 1988, 108, 221.

4. L. Gleb. In: Virology. B.N. Fields et al. (eds.), Raven Press, N.Y., 1990, 2011.

5. J.M. Ostrove, Adv. Virus Res., 1990, 38, 45.

6. R. Snoeck, G. Andrei, E De Clercq. Intern. J. Antimicrob. Agents, 1994, 4, 211.

7. K.J. Smith, C. Kahlter, C. Davis, W.D. James, H.G. Skelton, B. Angriff. Arch. Dermatol. 1991, 127, 1069.

8. C.C. Linnemann, K.K. Biron, W.G. Hoppenjans, A.M. Solinger. AIDS, 1990, 4, 577.

9. R.J. Whitley, M. Hilty, R. Hynes, Y. Brison, J.D. Connor, S.J. Soong, C.A. Alford. J. Pediatr. 1982, 101, 125.

10. A.M. Arvin, J.H. Kushner, S. Foldman, R.L. Buchner, D. Itmond, T.C. Merigan. N. Engl. J. Med. $1982,1,125$.

11. T. Varadinova, I. Pavlov, D. Dimitrov, C. Nachev, P. Bontchev, B. Evtimova. Compt. Rend. de l'Acad. Bulg. Sci. 1990, 11, 131.

12. T.L. Varadinova, P.R. Bontchev, C.K. Nachev, S.A. Shishkov, D. Strachilov, Z. Paskalev, A. Toutekova, M. Panteva. J. Chemotherapy, 1993, 5, 1, 3.

13. L. Reed, H. Muench. An. J. Hyg., 1938, 21, 493.

Received: March 2, 1995 - Accepted: April 19, 1995 - Received in revised camera-ready format: December 6, 1995 